\title{
ANALISIS KEPADATAN MAKROZOOBENTOS PADA FASE BULAN BERBEDA DI LAMUN, PULAU PANGGANG, KEPULAUAN SERIBU JAKARTA
}

\section{ANALYSIS OF MACROZOOBENTHIC DENSITY AT DIFFERENT MOON PHASES IN SEAGRASS, PANGGANG, SERIBU ISLANDS JAKARTA}

\author{
Iswandi Wahab ${ }^{1}$, Hawis Madduppa ${ }^{2}$, Mujizat Kawaroe ${ }^{2}$, Nurafni $^{1}$ \\ ${ }^{1}$ Fakultas Perikanan dan Ilmu Kelautan, Universitas Pasifik Morotai \\ ${ }^{2}$ Departemen Ilmu dan Teknologi Kelautan, \\ Fakultas Perikanan dan Ilmu Kelautan, Institut Pertanian Bogor \\ Korespondensi: iswandi.fpik@gmail.com
}

\begin{abstract}
Seagrass ecosystems are inhabited by many species of benthic invertebrates, demersal and pelagic organisms that reside or stay temporarily in seagrass ecosystems. This research aimed to analyze the density of the macrozoobenthos in two different moon phases and to seek the contribution of each macrozoobenthic species in each research stations at seagrass beds. Sampling of the macrozonthic organisms was taken in three research stations of Panggang Island (west, east, and south) by using a $1 \mathrm{x} 1 \mathrm{~m}$ of quadratic transect and a sediment corer with $10 \mathrm{~cm}$ in diameter. The data analysis statistically analysis data was carried out by finding out the similarity percentage of the species contribution using SIMPER test. Results of this research indicate that the discovered macrozoobenthos for two phases of moon are varied in each station. The total found macrozoobenthos during two moon phases are 28 and 11 species in the west station, 24 and 20 species in the east station, and 18 and 24 species in the south station, respectively. In the three stations, the two highest and the lowest species density of macrozoobenthos during the two moon phases namely are Cerithium salebrosum (283 ind $/ \mathrm{m}^{2}$ ) and Cerithium punctatum (169 ind $\left./ \mathrm{m}^{2}\right)$; and Geotrochus multicarinatum $\left(7 \mathrm{ind} / \mathrm{m}^{2}\right)$. Moreover, the most contributor species of macrozobenthos in the seagrass habitat of the entire stations is Cerithium salebrosum.
\end{abstract}

Keywords: contribution, density, macrozoobenthic, Panggang islands

\begin{abstract}
ABSTRAK
Ekosistem lamun dihuni oleh banyak jenis invertebrata bentik, organisme demersal serta pelagis yang menetap maupun yang tinggal sementara di ekosistem lamun. Penelitian ini bertujuan untuk menganalisis kepadatan makrozoobentos dalam dua fase bulan yang berbeda dan mengetahui kontribusi setiap spesies makrozoobentos di setiap stasiun penelitian di padang lamun. Pengambilan sampel organisme makrozoobentos diambil di Pulau Panggang pada tiga stasiun pengamatan (barat, timur, dan selatan) dengan menggunakan transek quadrat 1 × $1 \mathrm{~m}$ dan corer sedimen dengan diameter $10 \mathrm{~cm}$. Analisis data secara statistik, analisis data dilakukan dengan mencari tahu persentase kesamaan kontribusi spesies menggunakan uji SIMPER. Hasil penelitian ini menunjukkan bahwa macrozoobentos yang ditemukan untuk dua fase bulan bervariasi di setiap stasiun. Total makrozoobentos yang ditemukan selama dua fase bulan adalah 28 dan 11 spesies di stasiun barat, 24 dan 20 spesies di stasiun timur, dan 18 dan 24 spesies di stasiun selatan, masing-masing. Di ketiga stasiun, dua jenis spesies makrozoobentos tertinggi dan terendah selama dua fase bulan yaitu Cerithium salebrosum (283 ind $/ \mathrm{m}^{2}$ ) dan Cerithium punctatum (169 ind $/ \mathrm{m}^{2}$ ); dan Geotrochus multicarinatum (7 ind $/ \mathrm{m}^{2}$ ). Selain itu, spesies makrozoobentos yang paling banyak di habitat lamun di seluruh stasiun adalah Cerithium salebrosum.
\end{abstract}

Kata kunci: densitas, kontribusi, makrozoobentos, Pulau Panggang 


\section{PENDAHULUAN}

Padang lamun dihuni oleh banyak jenis invertebrata bentik, organisme demersal serta pelagis yang menetap maupun yang tinggal sementara di ekosistem lamun. Ekosistem tersebut merupakan sumber makanan penting bagi banyak organisme dan dimanfaatkan oleh biota laut sebagai tempat memijah (Dorenbosch et al. 2006). Perairan Pulau Panggang, Kepulaun Seribu Jakarta memiliki 6 jenis lamun dengan tingkat asosiasi biota yang cukup kompleks (Wahab et al. 2017). Salah satu kelompok fauna yang umumnya ditemukan di perairan pesisir khususnya di daerah padang lamun dan hidup berasosiasi yaitu makrozoobentos, baik yang hidup permukaan substrat (epifauna) maupun di dalam substrat (infauna).

$$
\text { Makrozoobentos mempunyai }
$$

peranan penting di perairan sebagai bioindikator lingkungan, bioturbasi sedimen, dan pemakan bahan organik (Ira 2011; Marmita et al. 2013). Makrozoobentos yang hidup pada ekosistem lamun berpengaruh terhadap struktur rantai makanan (Ruswahyuni 2008). Selain itu, komposisi dan kepadatan makrozoobentos di lamun dapat menggambarkan kestabilan perairan yang kondusif dalam ekosistem lamun.

Kepadatan tutupan lamun dapat mempengaruhi keberadaan struktur kepadatan makrozoobentos. Kepadatan dan tutupan lamun yang tinggi mempengaruhi kelimpahan dan kepadatan makrozoobentos dibandingkan dengan kepadatan tutupan lamun yang rendah (Ira 2011). Kehadiran makrozoobentos sangat ditentukan oleh adanya vegetasi lamun yang ada di daerah pesisir. Kepadatan dan distribusi makrozoobentos dipengaruhi oleh faktor lingkungan setempat, ketersediaan makanan, pemangsaan, dan kompetisi. Tekanan dan perubahan lingkungan dapat mempengaruhi jumlah jenis dan perbedaan pada struktur komunitas makrozoobentos (Wahab et al. 2017).

Proses penyebaran makrozoobentos biasanya mengikuti pola arus pasang dan surut air laut dan tidak homogen dalam menempati lingkungan perairan. Proses pasang surut yang terjadi pada suatu perairan sangat berpengaruh terhadap kepadatan dan distribusi biota-biota laut termaksud beberapa genus makrozoobentos. Perbedaan kekuatan pasang ini secara teoritis dapat mempengaruhi kepadatan sepsies makrozoobentos antara periode waktu purnama dan perbani. Hal ini disebabkan sirkulasi masa air antara kedua periode bulan berbeda. Pasang laut purnama terjadi ketika bumi, bulan, dan matahari berada dalam suatu garis lurus. Sehingga dihasilkan pasang naik yang sangat tinggi dan pasang surutyang sangat rendah. Pasang laut perbani terjadi ketika bumi, bulan, dan matahari membentuk sudut tegak lurus. Pada saat itu akan dihasilkan pasang naik yang rendah dan pasang surut yang tinggi. Besarnya pengaruh dinamika parameter lingkungan di bulan purnama dan perbani dimana kondisi besarnya ruang pergerakan dan pendistribusian sumber makanan serta parameter fisika-kimia. Menurut Romimoharto dan Juana (2004), pengaruh periode bulan pada mintakat pasang surut sangat terkait dengan gejala pasang surut dan pencahayaan bulan sehingga secara biologis menstimulasi biota laut dalam hal penyebaran, pemangsaan, dan pemijahan. Sebuah perbedaan besar dalam sirkulasi masa air antara periode bulan perbani dan purnama menggambarkan kapasitas masa air berupa arus pasang surut untuk mendistribusikan sedimen, makanan, dan organik lainya.

Pengamatan pada periode bulan purnama dan perbani dilakukan dengan tujuan untuk 1) menganalisis kepadatan makrozoobentos antara kedua bulan, 2) Melihat kontribusi spesies makrozoobentos tertentu pada masing-masing stasiun di habitat lamun. Berdasarkan uraian diatas, maka dilakukan penelitian tentang "Analisis Kepadatan Makrozoobentos pada Fase Bulan Berbeda di Lamun, Pulau Panggang, Kepulauan Seribu Jakarta".

\section{METODE PENELITIAN}

Penelitian ini dilaksanakan di Pulau Panggang, Kepulauan Seribu Jakarta pada bulan Maret dan April 2016. Pengambilan data lamun dan makrozoobentos di 3 stasiun pengamatan dengan pendekatan fase bulan purnama dan bulan perbani. Pengamatan parameter ini meliputi identifikasi lamun, kerapatan, penutupan lamun, dan kepadatan makrozoobentos (Gambar 1).

\section{Alat dan bahan}

Alat dan bahan yang digunakan dalam penelitian ini yaitu plot kuadran untuk batas daerah pengambilan sampel, Global Positioning System (GPS) untuk 
menentukan posisi stasiun pengamatan, roll meter untuk mengukur luasan ekosistem lamun dan jarak antar stasiun, $\mathrm{pH}$ meter untuk mengukur $\mathrm{pH}$ perairan, corer $\left(A=0,0081 \mathrm{~m}^{2}\right)$ dan pipa paralon untuk sampling sampel makrozoobentos dan sedimen, refraktometer untuk mengukur salinitas perairan, termometer untuk suhu perairan, plastik foil (baki), pinset, kantong sampel plastik digunakan untuk menyimpan sampel makrozoobentos dan sedimen, kertas label digunakan untuk menandakan sampel, alkohol 70\% untuk mengawetkan sampel makrozoobentos, kamera untuk dokumentasi sampel dan kegiatan penelitian, dan buku identifikasi sampel lamun dan makrozoobentos yaitu buku siput dan kerang Indonesia Jilid I dan II serta Conchology Dharma (1992 dan 2005) dan buku identifikasi lamun (Waycott et al. 2004).

\section{Prosedur pengambilan data}

Pengambilan data vegetasi lamun menggunakan metode line transek kuadran berukuran 1 x $1 \mathrm{~m}$ (English et al. 1997), hal pertama yang dilakukan pengambilan data yaitu penarikan garis transek kuadran dari batas awal terdapat lamun hingga ujung batas keberadaan lamun dengan panjang garis transek 100 meter ke arah laut. Melakukan identifikasi jenis lamun yang ada berdasarkan pada panduan buku identifikasi lamun (Waycott et al. 2004), dan menghitung nilai kerapatan dan penutupan lamun pada kuadran.

Pengambilan data makrozoobentos pada vegetasi lamun dilakukan saat bulan purnama dan perbani dengan menentukan dan menempatkan plot secara permanen. Pengambilan sampel makrozoobentos didasarkan pada garis transek yang ditarik tegak lurus $100 \mathrm{~m}$ ke arah laut. Identifikasi dan koleksi sampel makrozoobentos tiap stasiun dilakukan pada tiap titik (terdapat 3 stasiun) menggunakan transek kuadran $1 \mathrm{x} 1 \mathrm{~m}$ (English et al. 1997) dengan 3 kali pengulangan di tiap stasiun. Sampel makrozoobentos infauna diambil dengan menggunakan corer berdiamater $10 \mathrm{~cm}$ yang ditancapkan pada sedimen hingga kedalaman $\pm 20 \mathrm{~cm}$ (Cochran 1977). Kemudian dilakukan pengoleksian sampel melalui tahapan penyaringan, penyortiran, identifikasi, dan pengawetan. Sampel infauna yang telah diambil segera disaring dan dipisahkan antara serasah daun, makrozoobentos, dan lumpur menggunakan saringan halus (mesh size $0,5 \mathrm{~mm}$ ). Sementara untuk spesies permukaan substrat hanya dihitung jumlah individu spesies pada transek kuadran masing-masing (Gambar 2).

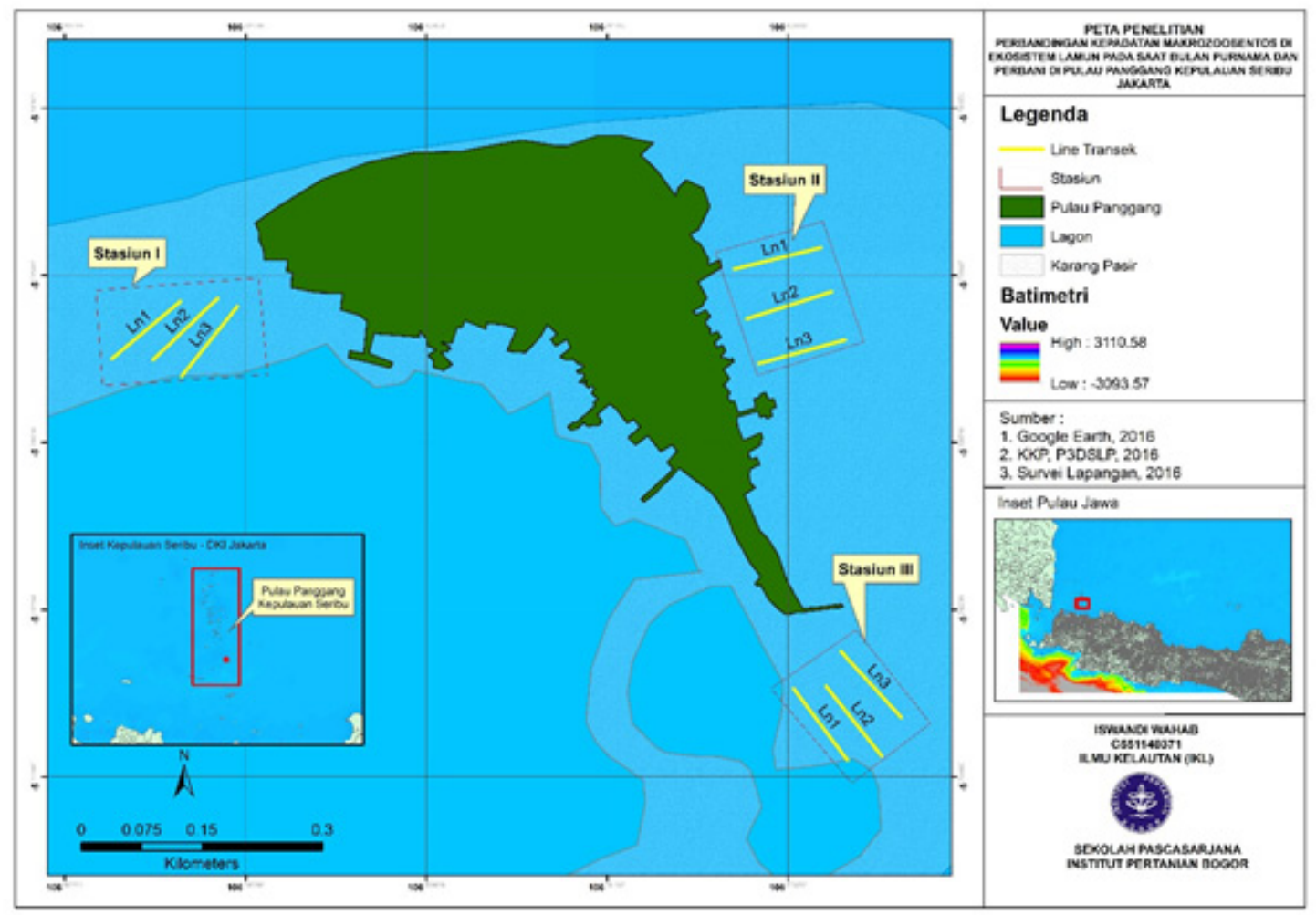

Gambar 1. Peta pengambilan sampel di Pulau Panggang 


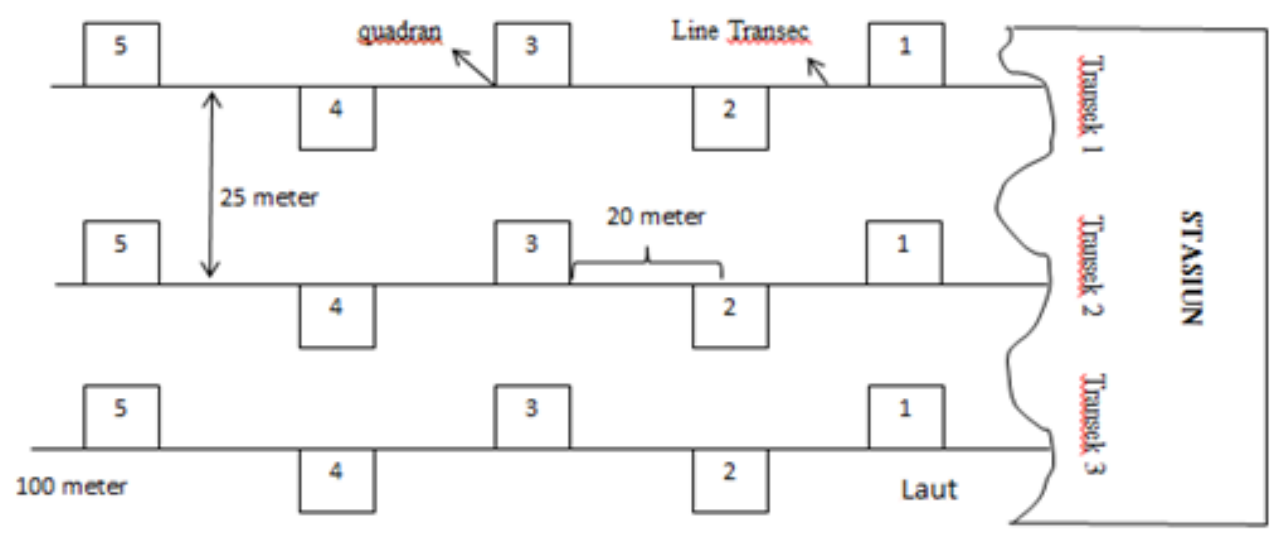

Gambar 2. Skema penempatan petak contoh sampling lamun

Data parameter lingkungan perairan diperoleh melalui pengukuran di lapangan secara in-situ baik suhu, arus, oksigen terlarut (DO), $\mathrm{pH}$, dan salinitas. Sedangkan untuk parameter substrat perairan diambil secara langsung dan dianalisis ukuran fraksinya pada laboratorium lingkungan Program Studi Budi Daya Perairan, Fakultas Perikanan dan Ilmu Kelautan, Institut Pertanian Bogor. Data hasil analisis uji korelasi parameter lingkungan perairan mengacu pada Wahab et al. (2018), yaitu pasir kasar 24,73\%, salinitas 31,23 ppt, pasir sangat halus $12,13 \%$, pasang surut $52 \mathrm{~cm}$, pasir halus $4,58 \%$, arus $0,47 \mathrm{~m} /$ det dan suhu $31,63^{\circ} \mathrm{C}$, di bulan purnama. Sementara di bulan perbani yaitu oksigen terlarut (DO) $8,23 \mathrm{mg} / 1$, pasir kasar 24,53\%, pasir halus $3,96 \%$, salinitas $31,17 \mathrm{ppt}$, dan pasang surut $29,67 \mathrm{~cm}$.

\section{Analisis data}

Kepadatan makrozoobentos dihitung berdasarkan rumus English et al. (1997) sebagai berikut:

$$
D i \frac{n i}{A}
$$

Dimana:

$D i$ : kepadatan individu jenis ke- $i$ (ind $/ \mathrm{m}^{2}$ ), $n i$ : jumlah individu ke-i yang diperoleh, dan $A$ : luas total area pengambilan contoh

\section{Analisis statistik}

Analisis statistik yang digunakan
dalam melihat kontribusi spesies makrozoobentos di lamun yaitu analisis SIMPER, perangkat lunak PRIMER v7
(Clarke dan Gorley 2006). Pengunaan analisis ini untuk melihat seberapa besar kontribusi jenis spesies makrozoobentos di setiap stasiun pengamatan.

\section{HASIL DAN PEMBAHASAN}

\section{Kepadatan makrozoobenthos di bulan purnama dan perbani}

Analisis data kepadatan suatu spesies di dalam komunitas, memiliki tujuan untuk mengestimasi populasi atau jumlah individu dari spesies tersebut dalam satuan luas tertentu. Pengamatan makrozoobentos di bulan purnama didapatkan 4 kelas yaitu bivalvia, gastropoda, crustacea dan porifera, sedangkan di perbani didapatkan 5 kelas yaitu bivalvia, gastropoda, echinodermata, porifera, dan crustacea. Nilai kepadatan makrozoobentos pada masing-masing stasiun dapat dilihat pada Gambar 3 dan Gambar 4.

Spesies makrozoobentos yang terdapat di stasiun bagian barat saat periode waktu bulan purnama terdiri dari 28 jenis. Nilai kepadatan makrozoobentos tertinggi pada stasiun pengamatan ini yaitu Cerithium salebrosum sebesar $\left(65 \mathrm{ind} / \mathrm{m}^{2}\right)$ kemudian di ikuti oleh Troncus $s p$ (46 ind/ $\left.\mathrm{m}^{2}\right)$ dan Cerithium punctatum (28 ind $\left./ \mathrm{m}^{2}\right)$, untuk Gibbula $s p$ sebesar (5 Ind $/ \mathrm{m}^{2}$ ), Tellina remies ( 3 Ind $\left./ \mathrm{m}^{2}\right)$, Paphia textile $\left(6\right.$ ind $\left./ \mathrm{m}^{2}\right)$, Cypraea eburna (11 ind $\left./ \mathrm{m}^{2}\right)$, dan Euthria sp $\left(23\right.$ ind $\left./ \mathrm{m}^{2}\right)$, Laemodonta punctigera (6 ind $\left./ \mathrm{m}^{2}\right)$, Clypeomorus colarium (9 ind $\left./ \mathrm{m}^{2}\right)$, Polinices tumidus (4 ind $\left./ \mathrm{m}^{2}\right)$, Rhinoclavis aspera (4 ind $\left./ \mathrm{m}^{2}\right)$, Rhinoclavis vertagus (5 ind $/ \mathrm{m}^{2}$ ), Coralliophila clathrata (3 ind/ $\mathrm{m}^{2}$ ), Trachycardium subrugosum (3 ind/ 
$\left.\mathrm{m}^{2}\right)$, Cerithium litteratum (5 ind $\left./ \mathrm{m}^{2}\right)$, Pyrene testudinaria $\left(8\right.$ ind $\left./ \mathrm{m}^{2}\right)$, Lioconcha tigrina $(8$ ind $/ \mathrm{m}^{2}$ ), Cypraea quadrimaculata (4 ind/ $\left.\mathrm{m}^{2}\right)$, Strombus canarium $\left(6 \mathrm{ind} / \mathrm{m}^{2}\right)$, Tellina virgata (4 ind $\left./ \mathrm{m}^{2}\right)$, Cerithium columna (8 ind/ $\left.\mathrm{m}^{2}\right)$, Vexillum plicarium (4 ind $/ \mathrm{m}^{2}$ ), Chicoreus torrefactus (6 ind $\left./ \mathrm{m}^{2}\right)$, Hamalopoma nocturnum (3 ind $\left./ \mathrm{m}^{2}\right)$, Petricolidae ( 7 ind/ m2), Columbella scripta (6 ind/m2), dan Nutricola lordi dengan nilai terendah sebesar (2 ind/m2) (Gambar 3).

Spesies makrozoobentos yang didapatkan pada bulan perbani di stasiun bagian barat terdiri dari 11 spesies. Nilai kepadatan makrozoobentos tertinggi yaitu C. salebrosum (47 ind $\left./ \mathrm{m}^{2}\right)$, diikuti oleh $C$. punctatum (35 ind $\left./ \mathrm{m}^{2}\right)$, dan Euthrina $s p$ sebesar $\left(15\right.$ ind $\left./ \mathrm{m}^{2}\right), E$. varians $\left(7\right.$ ind $\left./ \mathrm{m}^{2}\right), M$. serriale (5 ind $\left./ \mathrm{m}^{2}\right)$, R. multicostata (17 ind/ $\left.\mathrm{m}^{2}\right)$, Cypraea $\mathrm{sp}\left(7 \mathrm{ind} / \mathrm{m}^{2}\right)$, D. setosum (14 ind $\left./ \mathrm{m}^{2}\right)$, dan kepadatan terendah Troncus $s p\left(2\right.$ ind $\left./ \mathrm{m}^{2}\right)$, G. multicarinatum ( 2 ind $\left./ \mathrm{m}^{2}\right)$, $S$. canarium (2 ind $/ \mathrm{m}^{2}$ ) (Gambar 4).

Hasil analisis yang di dapatkan, dimana nilai kepadatan makrozoobentos tertinggi di stasiun bagian barat pada periode waktu bulan purnama yaitu spesies Cerithium salebrosum sebesar $\left(65 \mathrm{ind} / \mathrm{m}^{2}\right)$ dan terendah yaitu spesies Nutricola lordi (2 ind $/ \mathrm{m}^{2}$ ). Sedangkan di bulan perbani analisis kepadatan makrozoobentos didapatkan nilai tertinggi yaitu spesies Cerithium salebrosum sebesar (47 ind $/ \mathrm{m}^{2}$ ) dan terendah yaitu spesies Troncus $s p$, G. multicarinatum, dan $S$. canarium sebesar $\left(2 \mathrm{ind} / \mathrm{m}^{2}\right)$.

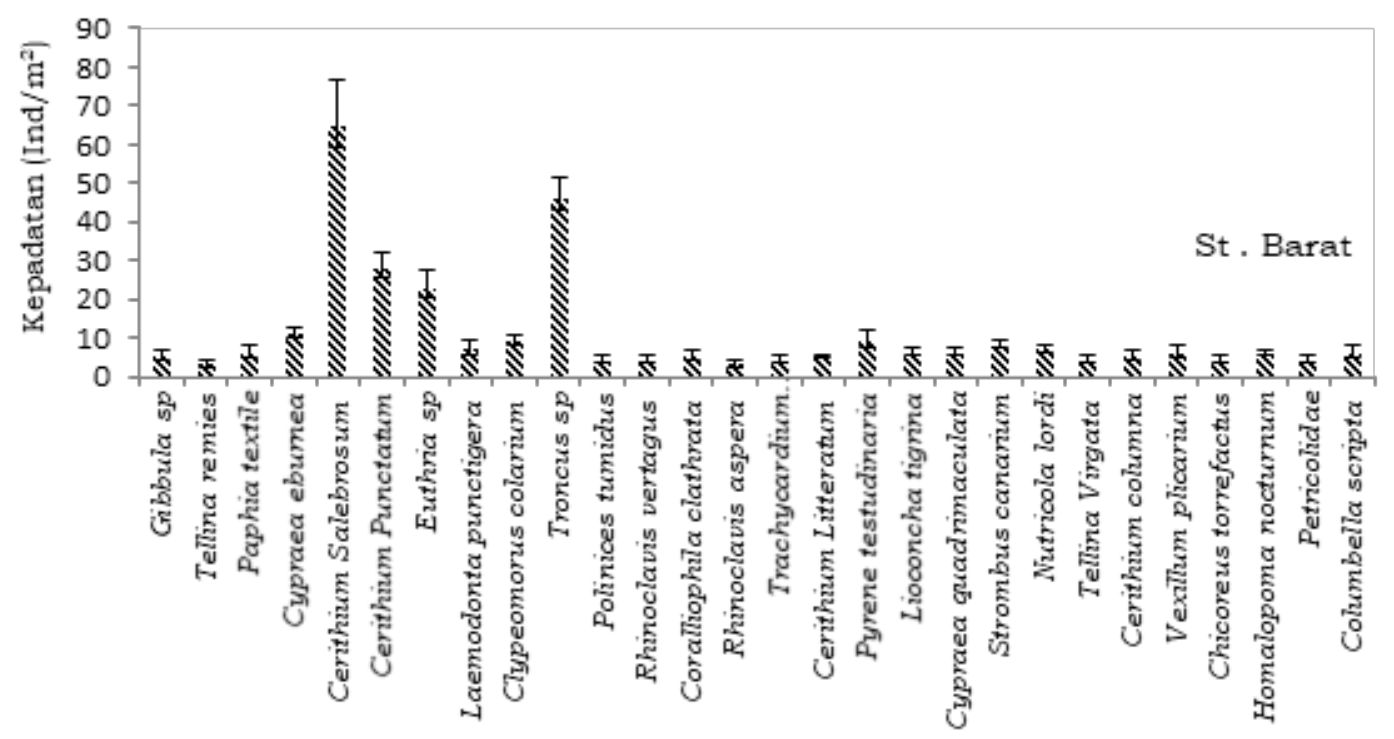

Gambar 3. Kepadatan jenis makrozoobentos di stasiun barat saat bulan purnama

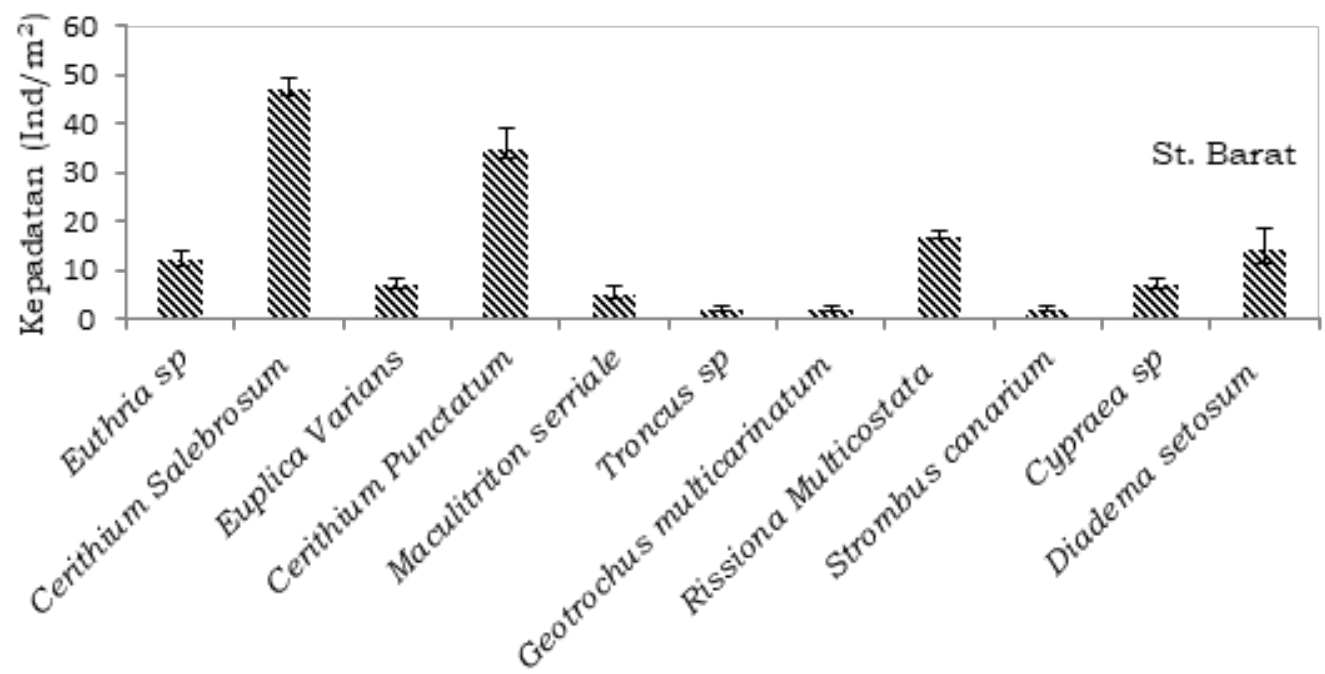

Gambar 4. Kepadatan jenis makrozoobentos di stasiun barat saat bulan perbani 
Spesies Cerithium salebrosum merupakan spesies siput laut genus Cerithium yang berasal dari famili Cerithidae yang paling banyak ditemukan pada bulan purnama dan perbani di stasiun barat. Spesies Cerithium salebrosum adalah spesies dari populasi gastropoda yang hidupnya meliang dan merayap di atas substrat berpasir diantara tegakan lamun. Tingginya kepadatan populasi gastropoda ini dipengaruhi oleh habitat lamun, substrat, parameter lingkungan, dan fase bulan saat sampling data. Kerapatan lamun Cymodocea rotundata pada stasiun bagian barat adalah 520 ind $/ \mathrm{m}^{2}$. Kerapatan lamun jenis Cymodocea rotundata merupakan jenis yang disukai oleh spesies Cerithium salebrosum (gastropoda), karena menyediakan serasah daun atau bahan organik (detritus feeder) yang sangat baik sebagai makanan dan habitat dibandingkan lamun jenis lainya. Kerapatan lamun yang tinggi memungkinkan epifauna untuk mendapatkan tempat perlindungan dan menyediakan sumber makanan dari serasah daun lamun (Metungun et al. 2011).

Pengaruh parameter lingkungan seperti salinitas, pasang surut, dan substrat memiliki korelasi positif dengan distribusi dan kepadatan spesies Cerithium salebrosum. Distribusi spesies ini mengikuti pola pergerakan pasang dan surut air laut. Menurut Derbali et al. (2012), keberadaan spesies gastropoda juga dipengaruhi oleh pergerakannya pada saat pasang naik yang merupakan penghindaran dari pemangsaan. Pada saat proses pasang surut air laut terjadi dibulan purnama spesies ini lebih cenderung menetap dan memijah, namun disaat bulan perbani spesies ini melakukan pergerakan untuk asosiasi dan mencari makan. Selain itu spesies Cerithium salebrosum menyukai perairan dengan salinitas yang optimum. Salinitas perairan yang berkorelasi saat sampling di bulan purnama dan perbani berkisar 31,23-31,17 (ppt).

Kondisi salinitas yang stabil ini mendukung keberadaan spesies Cerithium salebrosum dalam suatu wilayah perairan. Pengaruh parameter ini mirip dengan yang ditemukan Trivedi dan Vachhrajani (2013), bahwa parameter air laut seperti salinitas optimum berkorelasi dengan kepadatan dan sebaran spesies Cerithium scabridum di sepanjang pesisir Saurashtra, Gujarat India. Pada stasiun barat didapatkan substrat yang dominan yaitu substrat berpasir, kondisi ini ditandai dengan dominasi spesies yaitu Cerithium salebrosum dari populasi gastropoda. Menurut Nybakken (1992), tipe substrat berpasir memudahkan moluska untuk mendapatkan suplai nutrien dan air yang diperlukan untuk kelangsungan hidupnya. Tipe substrat berpasir juga akan memudahkan menyaring makanan yang diperlukan dibandingkan dengan tipe substrat berlumpur.

Hasil analisis kepadatan makrozoobentos di stasiun bagian timur perairan Pulau Panggang terdapat 24 spesies dengan nilai kepadatan tertinggi yaitu Troncus $s p$ sebesar $\left(24 \mathrm{ind} / \mathrm{m}^{2}\right)$, dan diikuti Cerithium salebrosum (21 ind $\left./ \mathrm{m}^{2}\right)$, $R$. vertagus sebesar (19 ind $\left./ \mathrm{m}^{2}\right)$, Chicoreus torrefactus (4 ind $\left./ \mathrm{m}^{2}\right)$, Cerithium punctatum (18 ind $\left./ \mathrm{m}^{2}\right)$, Strombus gibberulus (5 ind/ $\left.\mathrm{m}^{2}\right)$, Cypraea sp $\left(4 \mathrm{ind} / \mathrm{m}^{2}\right)$, Geotrochus multicarinatum ( 3 ind $\left./ \mathrm{m}^{2}\right)$, C. balteatum (18 ind $\left./ \mathrm{m}^{2}\right), F$. fragum (3 ind $\left./ \mathrm{m}^{2}\right), R$. aspera $(4$ ind $\left./ \mathrm{m}^{2}\right)$, C. microdon (4 ind $\left./ \mathrm{m}^{2}\right)$, kemudian S. anguina $\left(6\right.$ ind $\left./ \mathrm{m}^{2}\right)$, Conus $s p\left(3\right.$ ind $\left./ \mathrm{m}^{2}\right)$, $P$. reticulata $\left(4 \mathrm{ind} / \mathrm{m}^{2}\right)$, S. urceus sebesar $(4$ ind $\left./ \mathrm{m}^{2}\right), N$. lordi $\left(5\right.$ ind $\left./ \mathrm{m}^{2}\right), M$. fenestrate sebesar $\left(2\right.$ ind $\left./ \mathrm{m}^{2}\right)$, Euthria sp $\left(6\right.$ ind $\left./ \mathrm{m}^{2}\right), T$. virgata (4 ind $\left./ \mathrm{m}^{2}\right)$, C. nesioticum (11 ind $\left./ \mathrm{m}^{2}\right)$, T. californicum ( 5 ind $/ \mathrm{m}^{2}$ ), dan S. Aatol Aatol (4 ind $/ \mathrm{m}^{2}$ ) dan terendah yaitu T. radiata ( 2 ind $\left./ \mathrm{m}^{2}\right)$ (Gambar 5).

Sementara pengamatan bulan perbani di stasiun bagian timur, terdapat 20 jenis spesies makrozoobentos. Analisis nilai kepadatan memperlihatkan bahwa $C$. kobelti memiliki kepadatan tertinggi sebesar (57 ind $/ \mathrm{m}^{2}$ ), kemudian C. salebrosum (52 ind $\left./ \mathrm{m}^{2}\right)$, E. varians $\left(14\right.$ ind $\left./ \mathrm{m}^{2}\right)$, S. Aatol Aatol sebesar (5 ind $\left./ \mathrm{m}^{2}\right)$, Gibbula sp (20 ind/ $\left.\mathrm{m}^{2}\right)$, C. punctatum (45 ind $\left./ \mathrm{m}^{2}\right)$, Euthrina $\mathrm{sp}$ $\left(15\right.$ ind $\left./ \mathrm{m}^{2}\right), P$. textile sebesar $\left(5\right.$ ind $\left./ \mathrm{m}^{2}\right), R$. aspera (10 ind $\left./ \mathrm{m}^{2}\right)$, R. multicostata (16 ind/ $\left.\mathrm{m}^{2}\right), R$. vertagus (11 ind $\left./ \mathrm{m}^{2}\right)$, S. canarium (3 ind $\left./ \mathrm{m}^{2}\right)$, C. annulus $\left(3 \mathrm{ind} / \mathrm{m}^{2}\right)$, C. columna (6 ind $\left./ \mathrm{m}^{2}\right)$, G. multicarinatum sebesar (4 ind/ $\mathrm{m}^{2}$ ), H. nocturnum (4 ind $\left./ \mathrm{m}^{2}\right)$, dan terendah yaitu T. virgata $\left(2\right.$ ind $\left./ \mathrm{m}^{2}\right)$, C. afabica $(2$ ind $\left./ \mathrm{m}^{2}\right)$, P. eburna sebesar $\left(2\right.$ ind $\left./ \mathrm{m}^{2}\right), M$. fenestrata (2 ind $/ \mathrm{m}^{2}$ ) (Gambar 6).

$$
\text { Hasil analisis kepadatan }
$$

makrozoobentos di stasiun bagian timur di bulan purnama didapatkan kepadatan tertinggi yaitu spesies Troncus $s p$ sebesar $(24$ ind $\left./ \mathrm{m}^{2}\right)$ dan terendah adalah $T$. radiata $(2$ ind $/ \mathrm{m}^{2}$ ). Untuk pengamatan di bulan perbani nilai kepadatan tertinggi yaitu spesies $C$. kobelti sebesar $\left(57 \mathrm{ind} / \mathrm{m}^{2}\right)$ dan terendah 
adalah T. virgata, C. afabica, P. eburna dan $M$. fenestrata sebesar $\left(2\right.$ ind $\left./ \mathrm{m}^{2}\right)$. Individu spesies yang memiliki kepadatan tertingi pada kedua bulan tersebut mempunyai jenis yang berbeda yaitu Troncus $s p$ dan $C$. kobelti.

Spesies Troncus $s p$ dan C. kobelti merupakan kelompok siput laut dari famili Cerithidae, kedua spesies ini mendominasi di stasiun bagian timur pada bulan purnama dan perbani. Adanya perbedaan kepadatan kedua spesies diduga terkait kerapatan vegetasi lamun, parameter lingkungan, substrat, dan karakteristik kemunculan spesies pada fase bulan. Karakteristik dari spesies Troncus $s p$ bermunculan pada saat bulan purnama dan perbani sedangkan spesies C. kobelti hanya pada bulan perbani. Kepadatan Troncus $s p$ pada bulan purnama lebih mendominasi ketimbang bulan perbani, terkait dengan pengaruh parameter lingkungan suhu dan arus. Nilai kisaran suhu yang berkolerasi pada sampling bulan purnama $31,63^{\circ} \mathrm{C}$ dan kecepatan arus pada berkisar 0,47 ( $\mathrm{m} / \mathrm{det})$. Kisaran suhu yang optimum dan didukung dengan kecepatan arus yang sedang menjadikan suatu ruang hidup yang baik bagi keberadaan spesies tersebut.

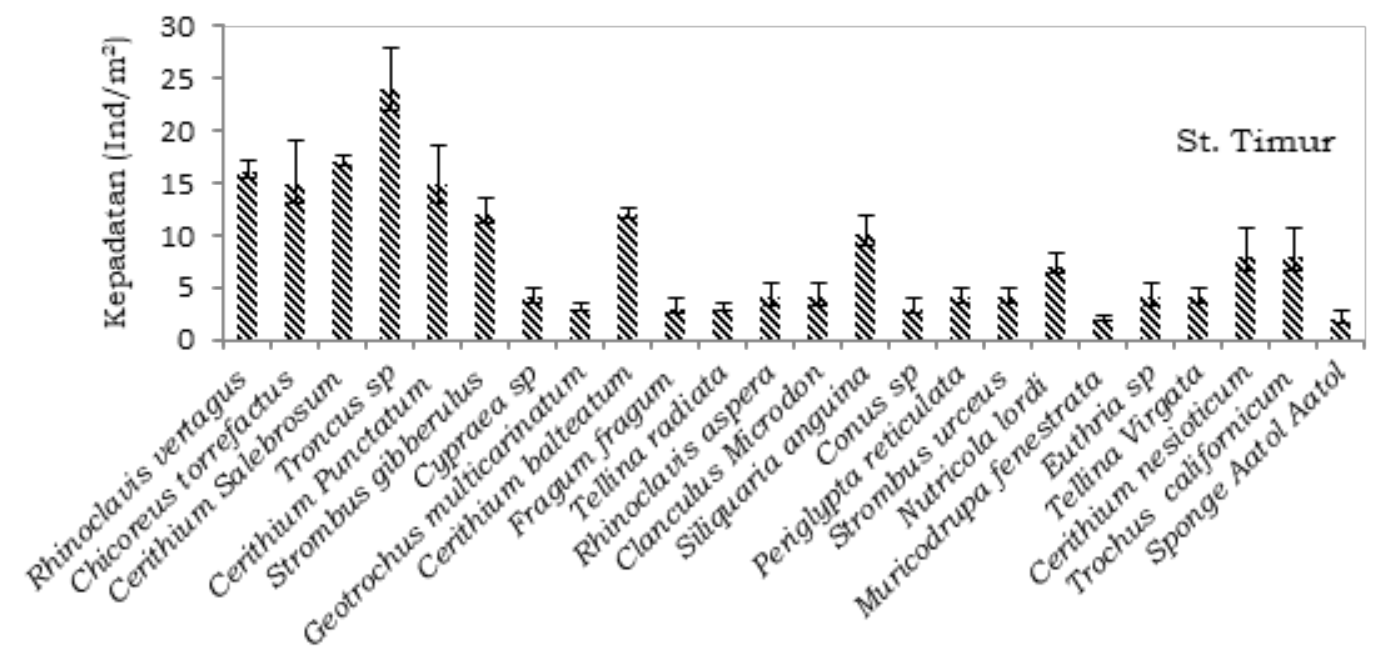

Gambar 5. Kepadatan jenis makrozoobentos di stasiun timur saat bulan purnama

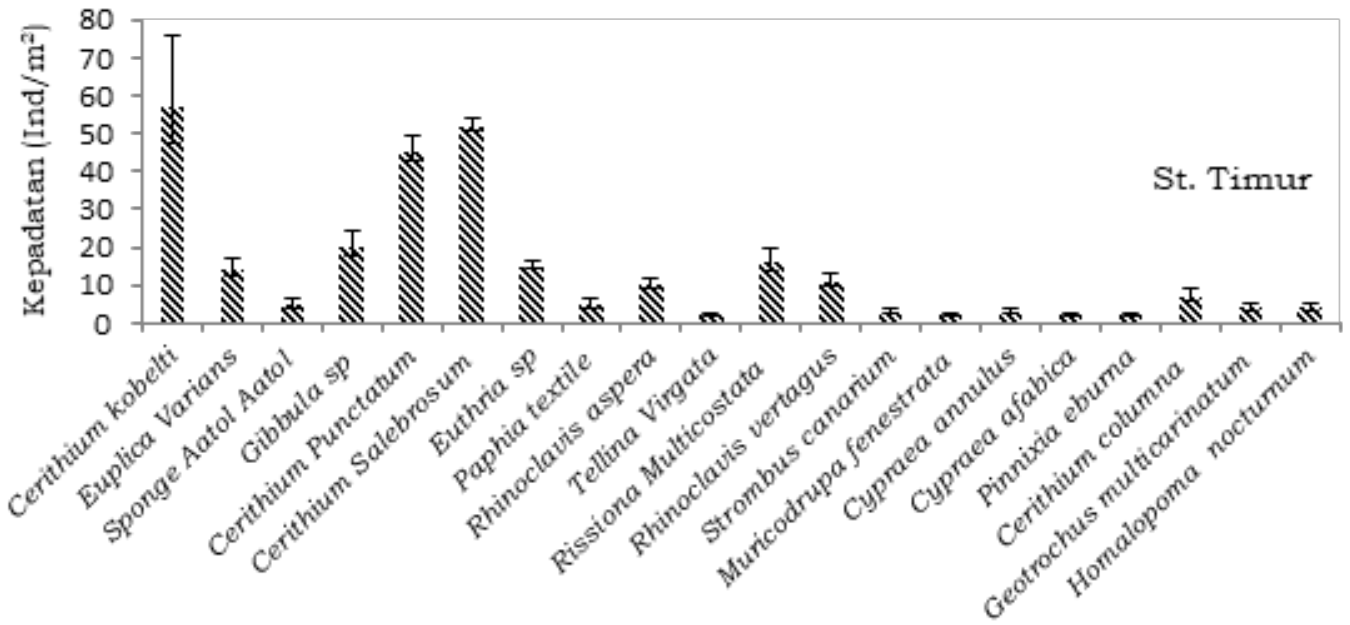

Gambar 6. Kepadatan jenis makrozoobentos di stasiun timur saat bulan perbani 
Menurut Hinz etal. (2011), perubahan suhu dapat mempengaruhi kepadatan dan keanekaragaman makrozoobentos. Suhu perairan mempengaruhi migrasi, laju metabolisme dan proses reproduksi terhadap makrozoobentos. Berdasarkan baku mutu yang ditetapkan oleh Kementrian Lingkungan Hidup (2004), maka suhu tersebut masih dalam rentan toleransi untuk biota laut. Arus dapat mempengaruhi sebaran atau perpindahan hewan makrozoobentos dari suatu tempat ke tempat lain. Menurut Hovel et al. (2002), mengatakan bahwa pergerakan air lebih berpengaruh terhadap kepadatan makrofauna dibandingkan dengan struktur lanskap lamun. Laju fotosintesis meningkat seiring bertambah kenaikan kecepatan arus, tetapi pada level tertentu laju fotosintesis tetap walaupun ada kenaikan kecepatan arus (Kordi 2011).

Berbeda dengan purnama, di bulan perbani parameter oksigen terlaut (DO) dan substrat perairan lebih berkorelasi dengan makrozoobentos terkait dengan tingginya kepadatan spesies C. kobelti. Nilai oksigen terlarut (DO) yang didapatkan berkolerasi yaitu $8,3(\mathrm{mg} / \mathrm{l})$. Berdasarkan keputusan Menteri Lingkungan Hidup No. 51 tahun 2004, kisaran tersebut masih dalam batas optimum kehidupan biota laut. Oksigen terlarut menjadi salah satu faktor mempengaruhi sebaran dan komposisi organisme makrozoobentos. Nilai kisaran substrat yang didapatkan berkorelasi yaitu pasir kasar $24,53 \%$ dan pasir halus $3,96 \%$. Dominasi substrat pasir dengan kategori yang berbeda di lokasi menjadi perbedaan dasar dari parameter lingkungan di lokasi lain. Menurut Nybakken dan Bertness (2004), menyatakan bahwa ukuran partikel suatu substrat berkaitan dengan penyebaran organisme dan kelimpahannya terletak pada retensi air dan kesesuaiannya untuk digali. Hal ini terkait dengan dominasi spesies C. kobelti dari Gastropoda yang banyak ditemukan pada lokasi penelitian. Substrat sebagai tempat hidup dari moluska khususnya gastropoda sangat mempengaruhi jumlah jenisnya (Cappenberg 2006). Substrat pasir kasar yang dominan merupakan tempat pemijahan yang baik bagi jenis ini, karena masuk pada kategori spesies epifauna. Substrat pasir memudahkan spesies ini dalam mensuplai nutrisi dan air untuk kelangsungan hidupnya juga untuk menghindar dari predator dengan cara masuk ke dalam pasir.
Kedua spesies dari gastropoda ini biasanya berasosiasi dengan vegetasi lamun pioner banyak kandungan zat hijau daun (klorofil) dan kerapatan yang tinggi. Kerapatanlamunyangtinggidistasiun bagian timur yaitu Cymodocea rotundata dengan nilai kerapatan yaitu 483 ind $/ \mathrm{m}^{2}$. Tingginya kerapatan dikarenakan lamun tersebut mendominasi di stasiun timur. Spesies lamun Cymodocea rotundata merupakan jenis yang survive memiliki wilayah sebaran yang luas dikarenakan dapat mentolerir perubahan kondisi perairan (Tomasick 1997). Peranan lamun dalam menahan laju sedimentasi, meredam kecepatan arus menjadikan kondisi perairan intertidal tenang dan membentuk ruang asosiasi yang baik bagi organisme makrozoobentos. Namun berbeda penelitian yang didapatkan (Cappenberg 1996), di perairan pulau Osi Seram Barat, dimana kepadatan spesies makrozoobentos Strombus urceus dari famili Strombidae yang di temukan lebih banyak 421 ind $/ \mathrm{m}^{2}$ di lamun jenis Cymodocea rotundata. Perbedaan kepadatan ini dikarenakan substrat yang mendominasi adalah pasir berlumpur sehingga sifat dari famili strombidae yang herbivora dapat hidup di perairan tersebut.

Perubahan lingkungan dalam faktor abiotik dan sifat kimia air laut memiliki efek menonjol pada distribusi biota di daerah intertidal suatu perairan. Akibatnya spesies dari organisme tertentu menggunakan strategiyang berbeda-beda dalam melakukan penyesuaian diri. Hal ini dilihat dari terjadi pembentukan sedimen (bioturbasi), sebagai habitat pada komunitas tertentu di stasiun bagian timur. Keberadaan gastropoda yang mendominasi distasiun timur, diduga sebagai salah satu yang membentuk bioturbasi. Menurut Taurusman (2010), makrozoobentos membutuhkan pasir untuk melakukan proses bioturbasi. Proses bioturbasi merupakan hasil egesi, gangguan, peningkatan kadar oksigen pada kedalaman yang lebih dalam dan pembentukan habitat yang cocok untuk kolonisasi lebih lanjut (Gray dan Elliot 2009). Selain itu faktor eksternal juga mempengaruhi kepadatan makrozoobentos khususnya jenis epifauna.

Stasiun bagian selatan di bulan purnama, terdapat 18 individu spesies makrozoobentos dengan nilai kepadatan bervariasi. Nilai kepadatan makrozoobentos tertinggi yaitu Cerithium salebrosum (28 ind $\left./ \mathrm{m}^{2}\right)$, kemudian Troncus $s p\left(18\right.$ ind $\left./ \mathrm{m}^{2}\right)$, C. colarium sebesar $\left(9 \mathrm{ind} / \mathrm{m}^{2}\right)$, T. remies (3 
ind $\left./ \mathrm{m}^{2}\right)$, Strombus urceus (12 ind $\left./ \mathrm{m}^{2}\right), V$. fimbriatum sebesar (4 ind $\left./ \mathrm{m}^{2}\right)$, C. asselus (4 ind $\left./ \mathrm{m}^{2}\right), H$. nocturnum $\left(2\right.$ ind $\left./ \mathrm{m}^{2}\right), C$. punctatum $\left(8\right.$ ind $\left./ \mathrm{m}^{2}\right)$, $P$. testudinaria $(6$ ind $\left./ \mathrm{m}^{2}\right)$, Cypraea $\mathrm{sp}\left(5 \mathrm{ind} / \mathrm{m}^{2}\right)$, Gibbula $\mathrm{sp}$ (7 ind $\left./ \mathrm{m}^{2}\right)$, C. litteratum (6 ind $\left./ \mathrm{m}^{2}\right)$, dan $F$. fragum $\left(3\right.$ ind $\left./ \mathrm{m}^{2}\right)$, dan terendah $P$. tumidus $\left(2\right.$ ind $\left./ \mathrm{m}^{2}\right), O$. auriscati $\left(2\right.$ ind $\left./ \mathrm{m}^{2}\right), \quad P$. reticulata $\left(2\right.$ ind $\left./ \mathrm{m}^{2}\right)$ dan Euthria $s p$ sebesar (2 ind $/ \mathrm{m}^{2}$ ) (Gambar 7 ).

Pada pengamatan di bulan perbani pada stasiun bagian selatan didapatkan 24 individu spesies makrozoobentos, dengan nilai kepadatan tertinggi spesies $R$. multicostata sebesar $\left(105 \mathrm{ind} / \mathrm{m}^{2}\right)$, kemudian C. salebrosum sebesar (74 ind $\left./ \mathrm{m}^{2}\right)$, S. urceus (4 ind $\left./ \mathrm{m}^{2}\right)$, E. varians sebesar $\left(38\right.$ ind $\left./ \mathrm{m}^{2}\right)$, C. colarium (3 ind $\left./ \mathrm{m}^{2}\right), F$. fragum ( 3 ind/ $\left.\mathrm{m}^{2}\right)$, V. fimbriatum (4 ind $\left./ \mathrm{m}^{2}\right)$, Euthrina $\mathrm{sp}$ (15 ind $\left./ \mathrm{m}^{2}\right)$, C. punctatum (38 ind $\left./ \mathrm{m}^{2}\right), S$. anguina $\left(8\right.$ ind $\left./ \mathrm{m}^{2}\right)$, S. purpureus (3 ind/ $\left.\mathrm{m}^{2}\right)$, V. plicarium $\left(3\right.$ ind $\left./ \mathrm{m}^{2}\right)$, C. columna (3 ind $\left./ \mathrm{m}^{2}\right)$, C. torrefactus $\left(4 \mathrm{ind} / \mathrm{m}^{2}\right), C$. balteatum ( 3 ind $\left./ \mathrm{m}^{2}\right)$, C. nesioticum (6 ind/ $\left.\mathrm{m}^{2}\right)$, B. reticulatum (f) jadertium (3 ind $\left./ \mathrm{m}^{2}\right), S$. canarium ( 3 ind $\left./ \mathrm{m}^{2}\right), I$. vanikorensis ( 3 ind/ $\left.\mathrm{m}^{2}\right)$, Gibbula sp $\left(6\right.$ ind $\left./ \mathrm{m}^{2}\right)$, dan terendah Pupa sulcata $\left(2\right.$ ind $\left./ \mathrm{m}^{2}\right), T$. radiatus (2 ind/ $\left.\mathrm{m}^{2}\right)$, C. denticulatus $\left(2\right.$ ind $\left./ \mathrm{m}^{2}\right)$, Cypraea $\mathrm{sp}$ (2 ind $\left./ \mathrm{m}^{2}\right)$ (Gambar 8).

Hasil analisis pada bulan purnama di stasiun selatan didapat nilai kepadatan tertinggi adalah spesies Cerithium salebrosum sebesar $\left(28\right.$ ind $\left./ \mathrm{m}^{2}\right)$ dan kepadatan terendah adalah spesies $P$. tumidus, $O$. auriscati, $P$. reticulata, dan Euthria $s p$ dengan nilai yang sama sebesar $\left(2\right.$ ind $/ \mathrm{m}^{2}$ ). Sedangkan pada bulan perbani di stasiun selatan, nilai kepadatan tertinggi adalah spesies $R$. multicostata sebesar (105 ind $/ \mathrm{m}^{2}$ ) dan kepadatan terendah adalah
Pupa sulcata, T. radiatus, C. denticulatus dan Cypraea $s p$ dengan nilai yang sama sebesar $\left(2\right.$ ind $\left./ \mathrm{m}^{2}\right)$.

Spesies Cerithium salebrosum dan R. multicostata merupakan populasi gastropoda yang memiliki karakteristik kemunculan berbeda, dimana Cerithium salebrosum pada bulan purnama dan perbani, sedangkan $R$. multicostata hanya pada bulan perbani. Perbedaan keberadaan kedua spesies dipengaruhi oleh faktor habitat lamun, struktur substrat, pasang surut air laut dan salinitas serta karakter kemunculan. Adanya korelasi antara parameter lingkungan pasang surut (pasut), struktur substrat dasar perairan dengan spesies Cerithium salebrosum. Nilai kisaran pasang surut yang berkorelasi pada sampling bulan purnama $52 \mathrm{~cm}$, substrat pasir kasar $24,06 \%$ dan pasir halus 4,58\%. Menurut Veloso et al. 2003, sebaran organisme makrozoobentos baik kepadatan dan keragaman pada lingkungan intertidal dipengaruhi oleh beberapa faktor salah satunya pasang surut (pasut). Proses pasang surutnya air laut dimanfaatkan oleh makrozoobentos dalam melakukan asosiasi dilingkungan lamun. Substrat berpasir memudahkan spesies Cerithium salebrosum dalam mengsuplai nutrisi dan air untuk kelangsungan hidupnya. Sumich (1992) menyatakan organisme makrozoobentos yang umum dijumpai pada substrat berpasir adalah gastropoda, bivalvia, dan beberapa family capitellidea. Semakin halus substrat dasar perairan maka sangat baik dalam menjebak bahan organik yang tersuspensi. Menurut Riniatsih dan Kushartono (2009), bahwa semakin halus tekstur substrat dasar maka kemampuan dalam menjebak bahan organik semakin besar.

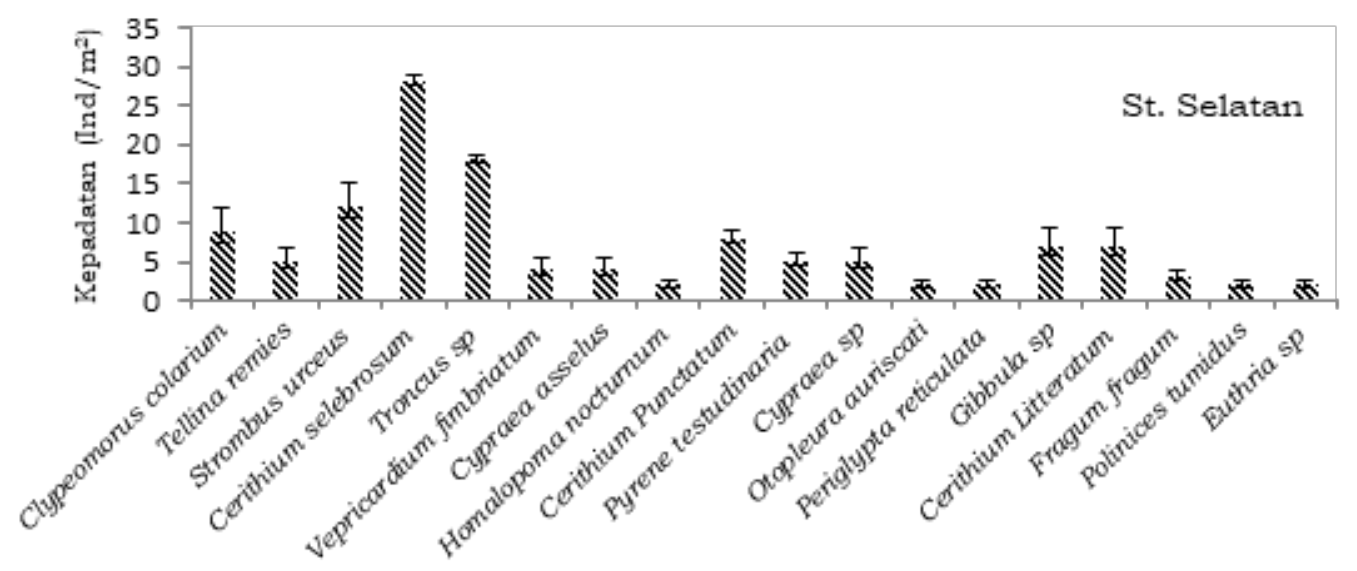

Gambar 7. Kepadatan jenis makrozoobentos di stasiun selatan saat bulan purnama 


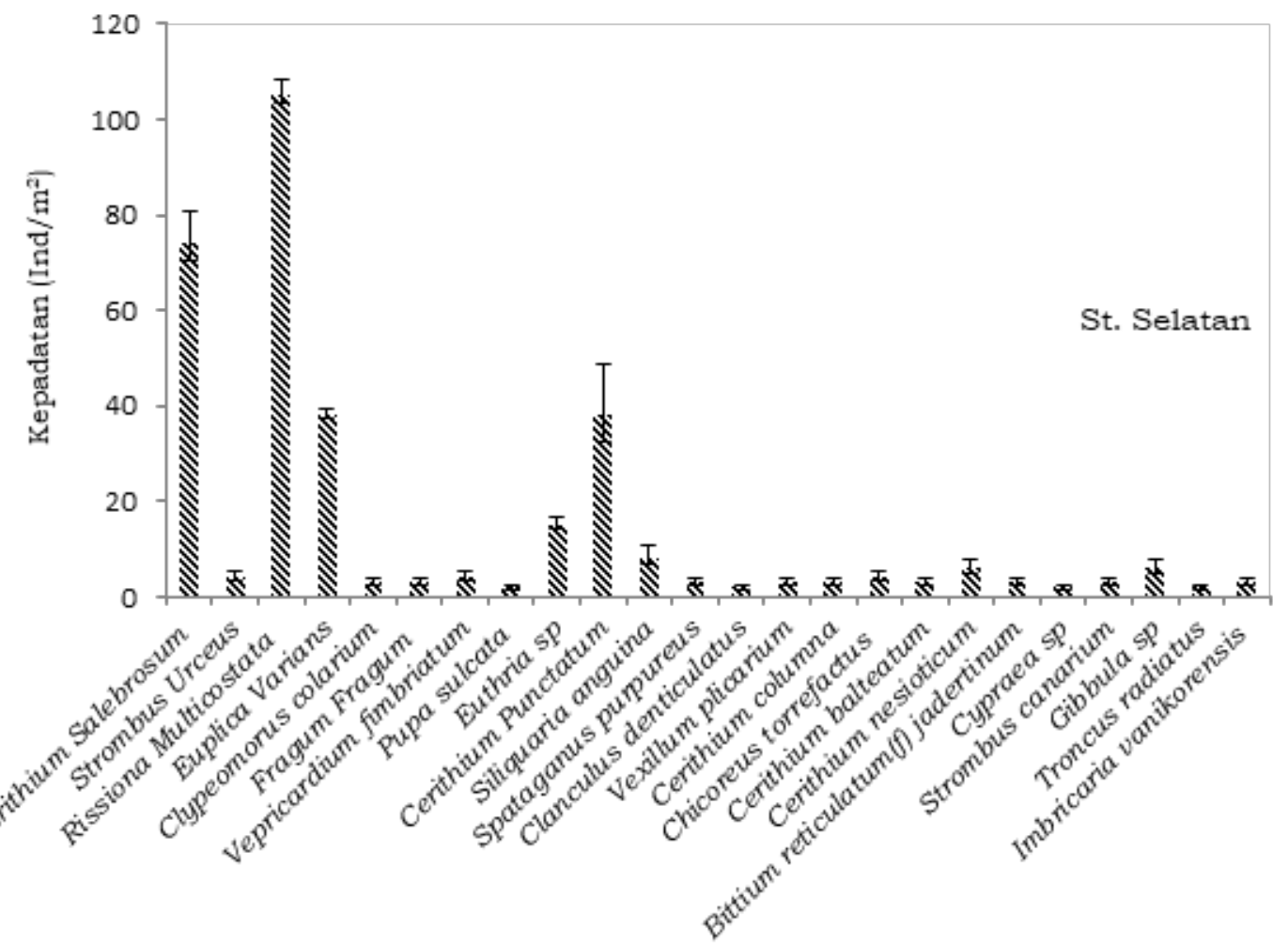

Gambar 8. Kepadatan jenis makrozoobentos di stasiun selatan saat bulan perbani

Sedangkan di bulan perbani parameter lingkungan yang berkorelasi dengan kepadatan spesies $R$. multicostata adalah salinitas dan substrat pasir halus. Nilai parameter yang berkorelasi baik salinitas dan pasir halus yaitu 31,43 ppt dan 4,58\%. Komunitas makrozoobentos dapat berfluktuasi dalam pola sebaran dari waktu ke waktu, karena karakteristik dari siklus hidup spesies, serta pengaruh struktur substrat dan faktor abiotik seperti salinitas (Das Neves et al. 2008). Selain itu perbedaan kepadatan kedua spesies terkait dengan kepadatan habitat jenis lamun yang berada di stasiun selatan. Jenis lamun yang mendominasi di stasiun selatan yaitu Thalassia hempricii dengan nilai kepadatan tertinggi dari jenis lainya sebesar 619 ind $/ \mathrm{m}^{2}$. Kerapatan daun dan struktur penutupan lamun berpengaruh terhadap keseimbangan penyebaran makrozoobentos termasuk spesies gastropoda (Hemminga dan Duarte 2000).

Tingginya kepadatan kedua spesies, diduga terkait dengan dominasi populasi gastropoda pada seluruh stasiun pengamatan sehingga berdampak pada sedikitnya spesies dari populasi lain. Rendahnya kepadatan makrozoobentos untuk spesies Tellina radiata (bivalvia) dan lainya, diduga karena kompetisi antara sesama filum molluska, yang didominasi oleh gastropoda. Hal ini mengakibatkan kompetisi ruang dan makanan antara sesama, yang akhirnya menghambat keberadaan organisme lain. Selain itu adanya jenis gastropoda yang bersifat predator dari genus Natica yang diduga mempengaruhi keberadaan populasi lain. Aktivitas penduduk lokal di sekitar pesisir dan faktor antropogenik juga mempengaruhi keberadaan makrozoobentos. Madduppa et al. (2013), keberadaan ekosistem dan organisme terkait pada perairan di Jakarta mengalami pengaruh dampak anktivitas atropogenik.

\section{Kepadatan makrozoobentos keseluruhan fase bulan}

Hasil analisis data kepadatan yang didapatkan bahwa spesies yang muncul pada keseluruhan fase bulan purnama dan perbani terdapat 25 spesies makrozoobentos. Nilai keberadaan kepadatan spesies makrozoobentos pada keseluruhan fase bulan berbeda-beda, dapat dilihat pada Gambar 9.

Hasil kepadatan spesies makrozoobentos terdapat di kedua bulan 
purnama dan perbani terdiri dari spesies Vepricardium fimbriatum $\left(8\right.$ ind $\left./ \mathrm{m}^{2}\right)$, Troncus sp $\left(90 \mathrm{ind} / \mathrm{m}^{2}\right)$, Vexillum plicarium (9 ind $\left./ \mathrm{m}^{2}\right)$, Strombus urceus $\left(20\right.$ ind $\left./ \mathrm{m}^{2}\right)$, Strombus canarium (16 ind $\left./ \mathrm{m}^{2}\right)$, Siliquaria anguina (18 ind $\left./ \mathrm{m}^{2}\right)$, Rhinoclavis aspera (17 ind $\left./ \mathrm{m}^{2}\right)$, Rhinoclavis vertagus (31 ind $/ \mathrm{m}^{2}$ ), Muricodrupa fenestrata (4 ind/ $\mathrm{m}^{2}$ ), Homalopoma noctorum (12 ind $\left./ \mathrm{m}^{2}\right)$, Chicoreus torrefactus (23 ind $\left./ \mathrm{m}^{2}\right)$, Euthria sp $\left(71 \mathrm{ind} / \mathrm{m}^{2}\right)$, Clypeomorus colarium (21 ind $\left./ \mathrm{m}^{2}\right)$, Cypraea $\mathrm{sp}\left(18\right.$ ind $\left./ \mathrm{m}^{2}\right)$, Cerithium columna (15 ind $\left./ \mathrm{m}^{2}\right)$, Cerithium salebrosum (283 ind $\left./ \mathrm{m}^{2}\right)$, Cerithium nesioticum (14 ind/ $\left.\mathrm{m}^{2}\right)$, Cerithium punctatum (169 ind $\left./ \mathrm{m}^{2}\right)$, Cerithium balteatum (15 ind $/ \mathrm{m}^{2}$ ), Gibbula $\mathrm{sp}$ (38 ind $\left./ \mathrm{m}^{2}\right)$, Sponge Aatol Aatol $\left(7\right.$ ind $\left./ \mathrm{m}^{2}\right)$, Tellina virgata $\left(10 \mathrm{ind} / \mathrm{m}^{2}\right)$, Paphia textile (11 ind $/ \mathrm{m}^{2}$ ), Geotrochus multicarinatum (7 ind/ $\mathrm{m}^{2}$ ), Fragum fragum (11 ind $/ \mathrm{m}^{2}$ ).

Persentasi nilai kepadatan tertinggi yaitu spesies Cerithium salebrosum sebesar 283 ind $/ \mathrm{m}^{2}$ dari kelompok gastropoda dan terendah yaitu Muricodrupa fenestrata sebesar 1,3 ind $/ \mathrm{m}^{2}$. Tingginya persentasi spesies tersebut diatas dikarenakan ditemukan mendominasi pada semua stasiun yang ada. Faktor habitat dan substrat perairan diduga menjadi faktor utama terkait tingginya komposisi spesies gastropoda tersebut. Adanya kesamaan habitat lamun pada ketiga stasiun yang terdiri dari jenis Cymodocea rotundata, Thalassia hempricii, dan Enhalus acoroides menjadi ketertarikan tersendiri bagi spesies makrozoobentos. Ketertarikan ini dipicu oleh bentuk marfologi baik akar, rhizome, batang, daun yang lebat dan substrat dasar berpasir sehingga sangat baik untuk tempat memijah dan mencari makan. Menurut Hemminga dan Duarte (2000), kerapatan dan struktur penutupan lamun berpengaruh terhadap keseimbangan penyebaran makrozoobentos, termaksud spesies gastropoda. Selain itu, banyaknya spesies makrozoobentos yang menyukai lamun jenis Cymodocea rotundata dikarenakan memiliki khas tersendiri berupa banyak mengandung zat klorofil yang memungkinkan dimanfaatkan oleh kelompok gastropoda dan moluska pada umumnya. Hal ini sesuai dengan Derbali et al. (2012), yang menemukan sebaran Cerastoderma glaucum (kerang) di lamun Cymodocea rotundata dan Cymodocea nodosa terkait dengan kandungan klorofil yang dimiliki oleh kedua lamun tersebut.

Selain faktor micro-habitat, pola atau cara makan juga secara secara spesifik mempengaruhi masing-masing spesies yang ada. Pola sebaran terkait dengan cara makan dimana spesies makrozoobentos tertentu akan mengelompok di daerah-daerah yang tersedia sumber bahan makanan yang baik. Hal ini dikarenakan sifat moluska dalam mencari makan yaitu sebagai detritus feeder dan pemakan mikroalga yang menempel di daun lamun. Menurut Odum (1993), pola sebaran terkait dengan cara makan akan membentuk spesies tertentu dalam mengelompok di daerah lamun yang tersedia sumber bahan makanan. Adanya keberadan 25 spesies makrozoobentos dari kelas gastropoda dan bivalvia diatas dikarenakan spesies tersebut memiliki tingkat asosiasi dalam menempati ruang yang cukup baik sehingga ditemukan berada pada semua stasiun di periode waktu yang berbeda.

\section{Kontribusi spesies di ekosistem lamun}

Spesies yang paling berkontribusi pada ekosistem lamun di masing-masing stasiun dapat dilihat pada Tabel 1 .

Hasil analisis data didapatkan bahwa pada stasiun barat yang terdiri dari lamun jenis Cymodocea rotundata, Thalassia hempricii, dan Enhalus acoroides ditemukan spesies makrozoobentos yang paling berkontribusi adalah Cerithium salebrosum $31,78 \%$, Cerithium punctatum 27,27\%, Euthria sp 9,76\%, Troncus sp 7,67\%, dan Rissiona multicostata 7,21\%. Pada stasiun timur yang terdiri dari lamun jenis Cymodocea rotundata, Thalassia hempricci, dan Enhalus acoroides ditemukan spesies makrozoobentos yang paling berkontribusi adalah Cerithium salebrosum 24,48\%, Cerithium punctatum 15,36\%, Rhinoclavis vertagus 14,08\%, Euthria sp 8,64\%, Rhinoclavis aspera 3,83\%, Troncus sp 3,73\%, Cerithium balteatum 3,63\%, Tellina virgata 3,31\%, Strombus gibberulus 3,30\%. dan untuk stasiun selatan yang terdiri dari lamun jenis Cymodocea rotundata, Cymodocea serulata, Thalassia hempricii, Enhalus acoroides, Halodule uninervis, dan Syringodium isoetifolium ditemukan spesies makrozoobentos yang paling berkontribusi adalah Cerithium salebrosum 37,41\%, Cerithium punctatum 17,88\%, Euthria $s p$ 9,26\%, Rissiona multicostata $8,19 \%$, dan Troncus sp 7,74\%.

Berdasarkan hasil analisis menggunakan uji SIMPER, didapatkan 5 spesies makrozoobentos yang berkontibusi di stasiun barat dengan kontribusi spesies 
yang paling tinggi adalah spesies Cerithium salebrosum. Stasiun timur memiliki kesamaan seperti stasiun barat didapatkan 5 spesies dengan kontribusi tertinggi yaitu Cerithium salebrosum sedangkan stasiun selatan memiliki komposisijauh lebih banyak dengan stasiun lainya, dimana terdapat 9 spesies makrozoobentos yang berkontribusi dan Cerithium salebrosum merupakan spesies yang tertinggi kontribusinya.

Spesies yang memiliki kontribusi paling tinggi di masing-masing stasiun adalah spesies Cerithium salebrosum dari komunitas gastropoda. Spesies Cerithium salebrosum ditemukan berada pada seluruh stasiun pengamatan dengan persentasi kepadatan dan kontribusi paling besar dari spesies lain. Kesamaan komposisi spesies pada stasiun barat dan timur, dikarenakan oleh komposisi habitat jenis lamun yang sama terdiri dari tiga jenis lamun dan substrat berpasir yang dominan. Sedangkan stasiun selatan memiliki perbedaan tersendiri, dimana terdapat 9 spesies yang berkontribusi dengan nilai kontribusi tertinggi yaitu spesies Cerithium salebrsosum. Selain itu pada stasiun selatan terdapat struktur habitat yang berbeda pada stasiun lainya dikarenakan terdapat 6 jenis lamun, namun memiliki substrat yang sama yaitu berpasir.

Kepadatan Makrozoobentos (ind $/ \mathrm{m}^{2}$ )

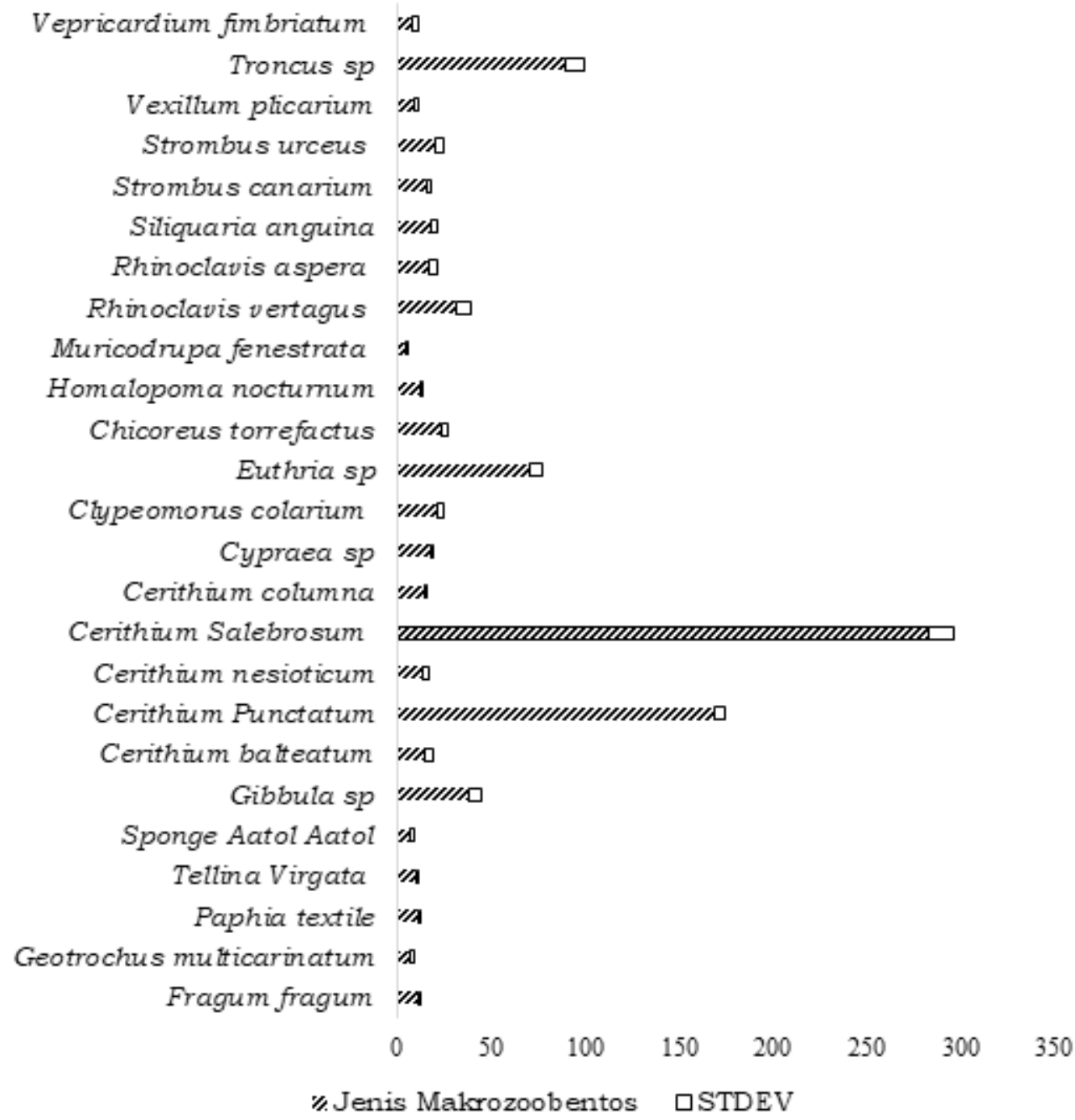

Gambar 9. Kepadatan spesies makrozoobentos berada pada kedua fase bulan (purnama dan perbani) 
Tabel 1. Spesies yang berkontribusi paling tinggi di setiap lokasi pengambilan sampel pada masing-masing stasiun menggunakan SIMPER (persentase kemiripan-kontribusi spesies)

\begin{tabular}{|c|c|c|c|c|}
\hline $\begin{array}{c}\text { Jenis } \\
\text { Makrozoobentos }\end{array}$ & $\begin{array}{c}\text { Av. } \\
\text { Abundance }\end{array}$ & $\begin{array}{c}\text { Av. } \\
\text { Similarity }\end{array}$ & $\begin{array}{c}\% \\
\text { Contribution }\end{array}$ & $\begin{array}{c}\text { Cumulative } \\
\%\end{array}$ \\
\hline \multicolumn{5}{|c|}{$\begin{array}{l}\text { St. Barat (Cr, Th, Ea) } \\
\text { Average similarity: } 38,11\end{array}$} \\
\hline Cerithium Salebrosum & 2,01 & 12,11 & 31,78 & 31,78 \\
\hline Cerithium Punctatum & 1,74 & 10,39 & 27,27 & 59,05 \\
\hline Euthria sp & 1,12 & 3,72 & 9,76 & 68,81 \\
\hline Troncus sp & 1,15 & 2,92 & 7,67 & 76,48 \\
\hline Rissiona Multicostata & 0,77 & 2,75 & 7,21 & 83,69 \\
\hline \multicolumn{5}{|c|}{$\begin{array}{l}\text { St. Timur (Cr, Th, Ea) } \\
\text { Average similarity: } 36,24\end{array}$} \\
\hline Cerithium Salebrosum & 1,79 & 8,87 & 24,48 & 24,48 \\
\hline Cerithium Punctatum & 1,49 & 5,57 & 15,36 & 39,84 \\
\hline Rhinoclavis vertagus & 1,26 & 5,10 & 14,08 & 53,92 \\
\hline Euthria sp & 0,97 & 3,13 & 8,64 & 62,56 \\
\hline Rhinoclavis aspera & 0,73 & 1,39 & 3,83 & 66,39 \\
\hline Troncus sp & 0,80 & 1,35 & 3,73 & 70,12 \\
\hline Cerithium balteatum & 0,70 & 1,32 & 3,63 & 73,75 \\
\hline Tellina virgata & 0,58 & 1,20 & 3,31 & 77,07 \\
\hline Strombus gibberulus & 0,69 & 1,20 & 3,30 & 80,37 \\
\hline \multicolumn{5}{|l|}{$\begin{array}{l}\text { St. Selatan }(\mathrm{Cr}, \mathrm{Cs}, \mathrm{Th}, \\
\text { Ea, Hu, Si) Average } \\
\text { similarity: } 32,48\end{array}$} \\
\hline Cerithium Salebrosum & 1,97 & 12,15 & 37,41 & 37,41 \\
\hline Cerithium Punctatum & 1,26 & 5,81 & 17,88 & 55,29 \\
\hline Euthria sp & 0,93 & 3,01 & 9,26 & 64,55 \\
\hline Rissiona Multicostata & 1,21 & 2,66 & 8,19 & 72,74 \\
\hline Troncus sp & 0,78 & 2,51 & 7,74 & 80,48 \\
\hline
\end{tabular}

Adanya Hubungan korelasi untuk spesies makrozoobentos yang bergantung pada habitat lamun sebagai tempat berlindung dan substrat dasar perairan. Distribusi spesies makrozoobentos tidak homogen dalam menempati suatu ruang atau habitat (Schneider 1994). Banyak proses yang berbeda, serta karakteristik fisiografi dan substrat mengatur pola temporal dan spasial terhadap keberadaan spesies (Legendre et al. 1997). Pola penyebaran itu memiliki korelasi dengan kepadatan lamun, ketersediaan makanan, tempat memijah dan berlindung untuk suatu keberlangsungan hidup komunitas spesies makrozoobentos. Kawaroe et al. (2016), dalam ekosistem perairan, makrozoobentos berperan sebagai salah satu mata rantai penghubung dalam aliran energi dan siklus dari alga planktonik sampai konsumen tingkat tinggi. Sedangkan fase bulan yang berbeda juga dapat mempengaruhi distribusi dan komposisi suatu populasi dari gastropoda yang mana sebagian memiliki karakteristik kemunculan berdasarkan fase waktu tertentu.

\section{KESIMPULAN DAN SARAN}

\section{Kesimpulan}

Kesimpulan penelitian ini yaitu:

1. Kepadatan tertinggi makrozoobentos antara bulan purnama dan perbani di stasiun barat yaitu spesies Cerithium salebrosum di bulan purnama, stasiun 
timur spesies Cerithium kobelti di bulan perbani dan stasiun selatan yaitu Rissiona multicostata di bulan perbani.

2. Spesies yang paling banyak berkontribusi di masing-masing stasiun pada habitat lamun yaitu Cerithium salebrosum.

\section{Saran}

Adanya kajian lanjutan terkait pola distribusi makrozoobentos di bulan purnama dan perbani berdasarkan pasang surut.

\section{DAFTAR PUSTAKA}

Cappenberg HAW, Aziz A, Aswandy I. 1996. Komunitas Moluska di Perairan Teluk Gilimanuk. Bali Barat. Oseanologi dan Limnologi di Indonesia. 39: 7587.

Cappenberg HAW. 2006. Komunitas Moluska di Perairan Teluk Gilimanuk. Bali Barat. Oseanologi dan Limnologi di Indonesia. 40: 53-64.

Clarke KR, Gorley RN. 2006. PRIMER v6: User Manual/Tutorial. Plymouth United Kingdom: PRIMER-E.

Cochran WG. 1977. Sampling Techniques 3rd Edition. Harvard Univesity. United State of America. New York.

Das Neves LP, da Silva P de SR, Bemvenuti CE. 2008. Temporal Variability of Benthic Macrofauna on Cassino Beach, Southhermost Brazil. Iheringia, Serie Zoologia. 98(1): 3644.

Derbali A, Elhasni K, Jarboui O. 2012. Distribution, Abundance, and Biological Parameters of Cerastoderma glaucum (Mollusca: Bivalvia) along the Gabes Coasts (Tunisia, Central Mediterranean). Cienc. Mar. Acta Adriatica. 53: 363374.

Dharma B. 1992. Siput dan Kerang Indonesia (Indonesian Shells II). Wiesbaden, Hemmen.

Dharma B. 2005. Recent \& Fosil Indonesia Shell. Conchbooks, Mainzer str, Hackenheim.

Dorenbosch M, Grol MGG, Nagelkerken I, Van der Velde G. 2006. Seagrass Beds and Mangroves as Nurseries for the Threatened Indo Pacific Humphead wrasse, Cheilinus undulatus, and Caribbean Rainbow parrotfish,
Scarus guacamaia. Biological Conservation. 129: 277-282.

English SWC, Baker V. 1997. Survey Manual for Tropical Marine Resources. Australian Institute of Marine Science. Townsville. Germany.

Gray JS, Elliot M. 2009. Ecology of Marine Sediments: from Science to Management. OUP Oxford.. ISBN. 9780198569015.

Hemminga MA, Duarte CM. 2000. Seagrass Ecology. Cambridge University Press. Inggris.

Hinz H, Capasso E, Lilley M, Frost M, Jenkins SR. 2011. Temporal Differences

Across A Bio-geographical Boundary Reveal Slow Response of Sublittoral

Benthos to Climate Change. Marine Ecology Progress Series. 423: 69-82. DOI: 10.3354/meps08963.

Hovel KA, Fonseca MS, Myer DL, Kneworthy WJ, Whitfield PE. 2002. Effect of Seagrass Landscape Structural Complexity and Hydrodynamic Regime on Macrofaunal Densities in North California Seagrass Beds. Mar. Ecol. Prog. Ser. 243: 11-24.

Ira. 2011. Keterkaitan Padang Lamun sebagai Pemerangkap dan Penghasil Bahan Organik dengan Struktur Komunitas Makrozoobentos di Perairan Pulau Barrang Lompo [Tesis]. Bogor: Institut Pertanian Bogor.

Kawaroe M, Nugraha AH, Juraij, Tasabaramo IA. 2016. Seagrass Biodiversity at Three Marine Ecoregions of Indonesia, Sunda Shelf, Sulawesi Sea, and Banda Sea. Indonesia. Bio Diversitas. 7(2): 585-591. DOI: 10.13057/biodiv/d170228.

Kordi MGHK. 2011. Ekosistem Lamun (Seagrass): Fungsi, Potensi, dan Pengelolaan. Rineka Cipta. Jakarta.

Legendre P. Thrush SF, Cummings VJ, Dayton PK, Grant J, Hewitt JE, Hines AH, McArdle BH, Pridmore RD, Schneider DC, Turner SJ, Whitlach RB, Wilkinson MR. 1997. Spatial Structure of Bivalves in A Sandflat: Scale and Generating Processes. Journal of Experimental. Marine Biology. 216: 99-128.

Madduppa H, Subhan B, Suparyani E, Siregar AM, Arafat D, Tarigan S, Alimuddin, Khairudi D, Rahmawati F, Bramandito A. 2013. Dynamics of Fish Diversity Across an Environmental 
Gradient in the Seribu Islands Reefs off Jakarta. Biodiversitas. 1: 17-24. DOI: $10.13057 /$ biodiv/d140103.

Marmita R, Siahaan R, Koneri R, Langoy ML. 2013. Makrozoobentos sebagai Indikator Biologis dalam Menentukan Kualitas Air Sungai Ranoyapo, Minahasa Selatan, Sulawesi Utara. Jurnal Ilmiah Sains, 13(1): 58-61.

Menteri Negara Lingkungan Hidup. 2004. Keputusan Menteri Negara Lingkungan Hidup Tentang Baku Mutu Air Laut Untuk Biota Laut. Jakarta: KEP No 51/ MENLH/I/2004.8 April 2004.

Metungun J, Juliana, Beruatjaan MY. 2011. Kelimpahan Gastropoda pada Habitat Lamun di Perairan Teluk UN Maluku Utara. Prosiding Seminar Nasional. Pengembangan PulauPulau Kecil. 225-231.

Nybakken JW. 1992. Biologi Laut: Suatu Pendekatan Ekologis. Gramedia Pustaka Utama. Jakarta.

Nybakken JW, Bertness MD. 2004. Marine Biology: An Ecological Approach. 6th ed. Benjamin Cummings.

Odum EP. 1993. Dasar-Dasar Ekologi. Gadjah Mada University Press. Yogyakarta.

Riniatsih I, Kushartono EW. 2009. Substrat Dasar dan Parameter Oseanografi sebagai Penentu Keberadaan Gastropoda dan Bivalvia di Pantai Sluke Kabupaten Rembang. Ilmu Kelautan. 14(1): 50-59.

Romimoharto K, Juwana S. 2004. Meroplankton Laut: Larva Laut yang Menjadi Plankton. Djambatan. Jakarta.

Ruswahyuni. 2008. Hubungan antara Kelimpahan Meiofauna dengan Tingkat Kerapatan Lamun yang Berbeda di Perairan Pantai Pulau Panjang Jepara. Jurnal Saintek Perikanan. 4(1): 35-41.

Schneider DC. 1994. Quantitative Ecology: Spatial and Temporal Scaling. Academic Press. San Diego.
Sumich JL. 1992. An Introduction to the Biology of Marine Life. Ed ke-5. Dubuque: WMC Borwn.

Taurusman A. 2010. Community Structure of Macrozoobenthic Feeding Guilds in Responses to Eutrophication in Jakarta Bay and Lampung Bay. 11(3): 133-138. DOI: 10.13057/ biodiv/d110306.

Tomasick T, Mah AJ, Nontji A, Moosa MK. 1997. The Ecology of the Indonesia Seas. Part One Periplus Edition. Singapore.

Trivedi JN, Arya S, Vachhrajani KD. 2013. Gastropoda Shell Utilization Preferences of Hermit Crab Clibanarius Zebra (Dana, 1852) (Diogenidae, Anomura). Taprobanica. 5(1): 12-18.

Veloso VG, Caetano CHS, Cardoso RS. 2003. Composition, Structure and Zonation of Intertidal Macroinfauna in Relation to Physical Factors in Microtidal Sandy Beaches in Rio de Janeiro State, Brazil. Scientia Marina. 67(4): 393-402.

Wahab I, Madduppa H, Kawaroe M. 2017. Seagrass Species Distribution, Density, and Coverage at Panggang Island, Jakarta. IOP Conf. Series: Earth and Environmental Science, 54012084 . http://iopscience.iop. org/ 17 55-1315/54/1/012084. [2 September 2017].

Wahab I, Madduppa H, Kawaroe M. 2018. Perbandingan Kelimpahan Makrozoobentos di Ekosistem Lamun Pada Saat Bulan Purnama dan Perbani di Pulau Panggang Kepulauan Seribu Jakarta. Jurnal Ilmu dan Teknologi Kelautan Tropis. 10(1): 217-229. DOI: http://dx.doi. org/10.29244/jitkt.v10i1.18974.

Waycott M, Mahon KM, Mellors M, Calladine A, Kleine D. 2004. A Guide to Tropical Seagrass of the Indo-West Pacific. Townsville-Queensland James Cook University. Australia. 